\title{
Detection and Quantification of the 16SrIV-D Phytoplasma in Leaf Tissue of Common Ornamental Palm Species in Florida using qPCR and dPCR
}

\author{
Brian W. Bahder, ${ }^{\dagger}$ Noemi Soto, Lidia Komondy, De-Fen Mou, Alessandra R. Humphries, and Ericka E. Helmick \\ Department of Entomology and Nematology, University of Florida-Fort Lauderdale Research and Education Center, Davie, \\ FL 33314-7719
}

\begin{abstract}
Lethal bronzing disease (LBD) is a lethal decline of various palm species caused by the 16SrIV-D phytoplasma. The disease was described in Texas in 2002 but found in Florida in 2006. Since its introduction, the phytoplasma has spread throughout much of the state. Typically, sampling of infected palms involves taking trunk tissue; however, in some instances this is not possible so alternative protocols are needed. In this study, phytoplasma titers were measured in different leaf tissues of infected palm in order to provide stakeholders with more sampling options. In addition, understanding the phytoplasma distribution in the palm canopy can shed light on the pathogen's biology and aid in vector studies. Three species of palm, Phoenix roebelinii, Sabal

species that represented different stages of decay were sampled and tested by qPCR and dPCR. For each species, phytoplasma was only detectable in the spear leaf tissue that was connected directly to the apical meristem by both qPCR and dPCR. These data are useful by demonstrating that the 16SrIV-D phytoplasma appears to be restricted to the spear leaf so stakeholders who wish to sample palms but cannot sample trunk tissue due to palm size or lack of permission to drill into the trunk have an alternative tissue type to reliably sample. In addition, this information will help improve vector research by knowing where to collect insects that have a higher probably of possessing the phytoplasma.
\end{abstract} palmetto, and Syagrus romanzoffiana, were identified and confirmed positive for infection by qPCR analysis. Leaf tissue from these
Keywords: palm, digital PCR, diagnostics, phytoplasma
Lethal bronzing disease (LBD), also known as Texas Phoenix Palm Decline (TPPD) and Date Palm Lethal Decline (DPLD), is a phytoplasma-caused disease that results in the death of susceptible host palm species. Symptoms of the disease include (i) premature fruit drop and/or inflorescence necrosis, (ii) bronzing of the older leaves that progresses upward into the canopy, and (iii) collapse of the spear leaf at which point the palm is dead (Harrison and Elliott 2016). The causal agent belongs to the 16SrIV taxonomic group and is designated as subgroup D (Harrison et al. 2002). This subgroup D phytoplasma was discovered in 2002 in Texas (Harrison et al. 2002) and was first detected in Hillsborough County, FL in 2006 from declining edible date palms (Phoenix dactylifera), Canary island date palm (P. canariensis), wild date palm ( $P$. sylvestris), and queen palm (Syagrus romanzoffiana) (Harrison et al. 2008). Since the discovery of the 16SrIV-D phytoplasma in Florida, it has been isolated from declining cabbage palms (Sabal palmetto) (Harrison et al. 2009), pygmy date palm (Phoenix roebelinii) (Jeyaprakash et al. 2011), Bismarck palm (Bismarckia nobilis) (Dey et al. 2018), and Carpentaria palm (Carpentaria acuminata) (Bahder et al., unpublished data).

The exact means by which the 16SrIV-D phytoplasma was introduced into Florida is unknown, but since its discovery it has spread to 22 counties throughout the state (Harrison and Elliott 2016). Recently, the introduction of the 16SrIV-D phytoplasma into a natural stand of S. palmetto at the University of Florida's Fort Lauderdale Research and Education Center (FLREC) in Davie, FL demonstrated secondary movement of the pathogen between palms (Bahder et al. 2018a), indicating vector-mediated transmission is occurring in

${ }^{\dagger}$ Corresponding author: B. W. Bahder; bbahder@ufl.edu

Funding: Funding for this project was provided by the Animal and Plant Health Inspection Service grant no. 8130-0148-CA.

The author(s) declare no conflict of interest.

Accepted for publication 20 February 2019.

(C) 2019 The American Phytopathological Society
Florida. Vector identification and management in Florida are going to be essential aspects of controlling LBD; however, at this moment current management options are limited to tree removal and preventative injections of oxytetracycline- $\mathrm{HCl}$ (OTC). One important aspect to tree removal is obtaining a fast and accurate diagnosis.

Recently, faster molecular tests have been developed that utilize quantitative PCR (qPCR) and melt curve analysis to distinguish between the 16SrIV-D phytoplasma and the 16SrIV-A phytoplasma (Bahder et al. 2017), which is the causal agent of lethal yellowing (LY), another lethal decline present in Florida that has historically impacted coconut palm (Cocos nucifera) (Bahder and Helmick 2018a). Additionally, digital PCR (dPCR) assays have been developed to increase sensitivity of phytoplasma testing (Bahder et al. 2018b), allowing for early detection, thus creating the opportunity to remove an infected tree from the environment sooner or initiate OTC injections before symptoms develop. All of these assays have been developed based on phytoplasma DNA sampled from palm trunks, which is historically the standard tissue for stakeholders (nursery and landscape personnel) to utilize. Despite the reliability of palm trunk tissue for sampling and testing, a common question at stakeholder meetings is about the potential use of leaf tissue as a source for diagnostic tests. Various circumstances may arise where trunk tissue is not available, such as a smaller palm exhibiting symptoms where no trunk has emerged yet or a customer who is not comfortable drilling a hole in the trunk of the palm. In these cases, being able to detect the phytoplasma in the leaf tissue would be valuable. In addition to benefiting stakeholders, understanding the distribution of the phytoplasma in palm canopies could provide valuable data to better understand the vector transmission pathway and overall ecology of the phytoplasma.

The primary objective of this study is to detect and quantify the phytoplasma in different leaf tissues from common ornamental palms in Florida that are infected with the 16SrIV-D phytoplasma.

\section{Materials and Methods}

Sample identification and collection. Palms exhibiting symptoms consistent with LBD were sampled according to the protocol by Bahder and Helmick (2018b). Trunk tissue was used to confirm infection status of symptomatic palms. Leaf tissue was sampled by taking five basal leaflets from palms with pinnate leaf structure. 
Leaflets were taken from leaves that were completely desiccated with a gray/brown color typical of naturally senescing leaves, desiccated leaves that possessed the bronze coloration typical of LBD, leaves that have begun desiccating but still maintain some healthy tissue, healthy appearing green leaves, and the spear leaf. Tissue taken from palms with palmate leaf structures was accomplished by peeling five sections and separating them at the junction with the petiole. Leaves exhibiting the same symptoms as previously described were selected for analysis.

DNA extraction. Total DNA was extracted from trunk and leaf tissue by macerating $1 \mathrm{~g}$ in guanidine buffer (guanidine thiocyanate $4 \mathrm{M}, 3 \mathrm{M}$ sodium acetate $-0.2 \mathrm{M}, 0.5 \mathrm{M}$ EDTA - $0.25 \mathrm{M}, \mathrm{PVP}-40$ $0.0006 \mathrm{M}$ ) in a BioReba extraction bag using the HOMEX6 tissue homogenizer. Lysate was then extracted using the Plant Mini Kit (Qiagen) as per the manufacturer's instructions. For leaf tissue, the basal portion of the five leaflet/leaf fragments were excised and used for the DNA extraction protocol. Total DNA in the final eluate was quantified using a NanoDrop Lite Spectrophotometer (ThermoFisher Scientific) and diluted to $25 \mathrm{ng} / \mu \mathrm{l}$ using the same AE buffer used for final elution step from the extraction kit.

Verification of isolate subgroup classification. To confirm identity of the phytoplasma in this study, all isolates were subjected to a melt curve analysis. All qPCR assays with melt curve analyses were performed in 20- $\mu$ l reactions comprised of $1 \mu \mathrm{l}$ of DNA template, $51.5 \%$ SsoFast EvaGreen with Low ROX supermix (Bio-Rad, Hercules, CA), 2\% polyvinyl pyrrolidone (MW 40,000)(PVP-40), $0.15 \mu \mathrm{M}$ of each primer, with the remaining volume made up with nuclease-free water. Primers used are PP16S-32 (Forward) and PP16S-163 (Reverse) from Bahder et al. (2017). Thermal cycling conditions for qPCR assays were as follows: initial denaturation at $95^{\circ} \mathrm{C}$ for 2 min followed by 35 cycles of denaturation at $95^{\circ} \mathrm{C}$ for $30 \mathrm{~s}$, annealing at $64^{\circ} \mathrm{C}$ for $30 \mathrm{~s}$, extension at $72^{\circ} \mathrm{C}$ for $15 \mathrm{~s}$ with endpoint detection, followed by HRMA, comprised of a denaturation step of $95^{\circ} \mathrm{C}$ for $30 \mathrm{~s}, 55^{\circ} \mathrm{C}$ for $1 \mathrm{~min}$, and $95^{\circ} \mathrm{C}$ for 1 min with continuous detection on the ramp cycle from $55^{\circ} \mathrm{C}$ to $95^{\circ} \mathrm{C}$ at $1.3 \%$ ramp

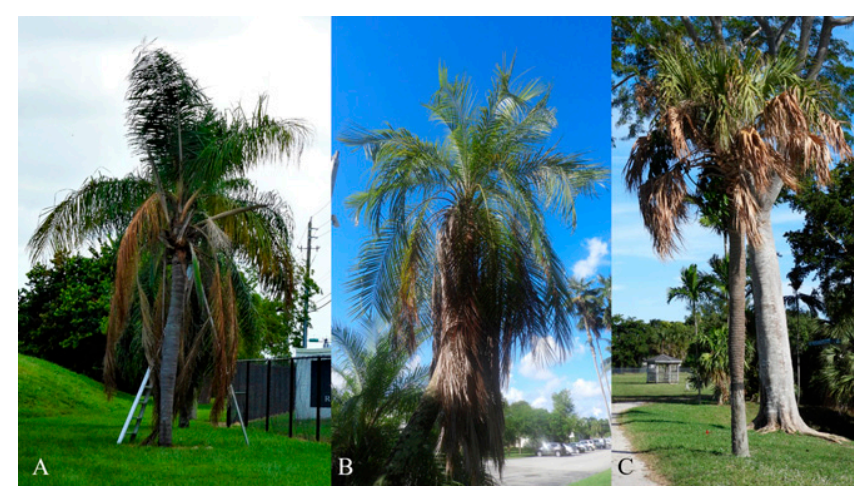

Fig. 1. Palms exhibiting symptoms of lethal bronzing used in this study and confirmed positive by GPCR: Phoenix roebelinii (A), Sabal palmetto (B), and Syagrus romanzoffiana (C). speed. Data were collected and analyzed using the QuantStudio RealTime PCR Software v1.3 (Life Technologies, Inc.). Results were compared with those of plasmid standard positive controls produced by Bahder et al. (2017) to identify subgroup for samples.

qPCR assay parameters and analysis. All qPCR reactions were performed on a QuantStudio 6 Flex Real-Time PCR System (Applied Biosystems, Inc.) and consisted of $10 \mu$ l of TaqMan Universal Master Mix II, with UNG, $10 \mu \mathrm{M}$ of each LY16S-LSF and -LSR primer, $10 \mu \mathrm{M}$ of LY16S probe, $10 \%$ PVP, $25 \mathrm{ng}$ of gDNA ( $1 \mu \mathrm{l})$, and sterile $\mathrm{dH}_{2} \mathrm{O}$ to a final volume of $20 \mu \mathrm{l}$. Córdova et al. (2014) designed both primers, LY16-LSF/LY16-LSR, and probe used in this assay. Reactions were subject to the following cycling parameters: $95^{\circ} \mathrm{C}$ for $10 \mathrm{~min}$, followed by 35 cycles of $95^{\circ} \mathrm{C}$ for $30 \mathrm{~s}, 60^{\circ} \mathrm{C}$ for $60 \mathrm{~s}$, and $72^{\circ} \mathrm{C}$ for $30 \mathrm{~s}$. Data were collected and analyzed using the QuantStudio Real-Time PCR Software v1.3 (Life Technologies, Inc.). All qPCR assays were run in triplicates per specimen.

Plasmid standard preparation. Standard PCR, using primers LY16-LSF/LY16-LSR (Córdova et al. 2014), was used for amplification of gDNA from sample Spa-12, which had tested positive for LBD. Each PCR contained 5× GoTaq Flexi Buffer, $25 \mathrm{mM} \mathrm{MgCl}_{2}$, $10 \mathrm{mM}$ dNTP's, $10 \mathrm{mM}$ each primer, $10 \%$ PVP-40, and $2.5 \mathrm{U}$ GoTaq Flexi DNA Polymerase, and sterile $\mathrm{dH}_{2} \mathrm{O}$ to a final volume of $25 \mu \mathrm{l}$. Thermocycling parameters were as follows: $94^{\circ} \mathrm{C}$ for $1 \mathrm{~min}$ initial denaturation, followed by 35 cycles of $94^{\circ} \mathrm{C}$ for $30 \mathrm{~s}, 60^{\circ} \mathrm{C}$ for $30 \mathrm{~s}$, $72^{\circ} \mathrm{C}$ for $30 \mathrm{~s}$, and a final extension of $72^{\circ} \mathrm{C}$ for $5 \mathrm{~min}$. Three $\mu \mathrm{l}$ of each product was electrophoresed on a $1.5 \%$ agarose gel stained with GelRed Nucleic Acid Gel Stain (Biotium, Hayward, CA) and visualized using ultraviolet transillumination. PCR products were cloned using a TOPO TA Cloning Kit into vector pCR 2.1-TOPO (Invitrogen) per the manufacturer's protocol. The cloning constructs were transformed into TOPO One Shot Chemically Competent E. coli cells and plated on LB plates containing $50 \mu \mathrm{g} / \mathrm{ml}$ Kanamycin. Plates were incubated overnight at $37^{\circ} \mathrm{C}$, and transformed colonies were chosen for colony PCR using primers LY16-LSF/LY16-LSR (Córdova et al. 2014) to verify that they contained the correct insert. Clones with the insert of the correct size were incubated on a shaker overnight in $20 \mathrm{ml} \mathrm{LB}$ broth with $50 \mu \mathrm{g} / \mathrm{ml}$ Kanamycin. Plasmids were extracted using a QIAprep Spin Miniprep Kit (Qiagen) per the manufacturer's protocol. Plasmid concentrations were quantified using a NanoDrop Lite Spectrophotometer (ThermoFisher Scientific, Waltham, MA). Ten-fold serial dilutions were created, $10^{8}$ to $10^{3}$, for use as standards in the qPCR assay.

dPCR assay parameters and analysis. All samples were subsequently screened by dPCR by diluting samples to $1 \mathrm{ng} / \mathrm{ml}$, as per the protocol and results presented by Bahder et al. (2018b). Digital PCR assays were performed in $14.5 \mu \mathrm{l}$, as per the manufacturer's instructions. Each reaction was comprised of $6 \mu \mathrm{l}$ of DNA template, $7.25 \mu \mathrm{l}$ of QuantStudio 3D Digital PCR Master Mix v2, $0.725 \mu$ of the custom copy number TaqMan assay, and $1.525 \mu \mathrm{l}$ of water. The primer sequences for the TaqMan assay are 5'-CCTGAGTAGTACG TACGCAAGT-3' (forward) and 5'-CAACATGATCCACCGCT TGTG-3' (reverse). The probe sequence is 5'-FAM-TCCCGTCAAT TCCTTTAAGTTTC-3'. Reaction mixtures were loaded on QuantStudio 3D Digital PCR 20K Chips v2 using the QuantStudio 3D

Table 1. Quantitative PCR results for the 16SrIV-D phytoplasma in leaf tissue at different stages of decay based on qPCR analysis

\begin{tabular}{|c|c|c|c|c|c|c|}
\hline \multirow[b]{2}{*}{ Sample } & \multicolumn{2}{|c|}{ Phoenix roebelinii } & \multicolumn{2}{|c|}{ Sabal palmetto } & \multicolumn{2}{|c|}{ Syagrus romanzoffiana } \\
\hline & $\mathbf{C t}$ & Quantitya $^{\mathbf{a}}$ & $\mathbf{C t}$ & Quantity $^{\mathbf{a}}$ & $\mathbf{C t}$ & Quantitya $^{\mathbf{a}}$ \\
\hline Trunk & $24.1 \pm 0.3$ & $79,000 \pm 10,622$ & $21 \pm 0.3$ & $573,802 \pm 162,850$ & $27 \pm 1.3$ & $24,948 \pm 12,582$ \\
\hline Leaf-1 & No $\mathrm{Ct}$ & 0 & No Ct & 0 & No $\mathrm{Ct}$ & 0 \\
\hline Leaf-2 & $\mathrm{No} C t$ & 0 & $\mathrm{No} C t$ & 0 & $\mathrm{No} C t$ & 0 \\
\hline Leaf-3 & $\mathrm{No} C t$ & 0 & No $\mathrm{Ct}$ & 0 & $\mathrm{No} C t$ & 0 \\
\hline Leaf- 4 & $20 \pm 0.1$ & $868,410 \pm 47,741$ & $\mathrm{No} C t$ & 0 & $\mathrm{No} C t$ & 0 \\
\hline Leaf-5 & $22 \pm 0.2$ & $370,471 \pm 45,377$ & $25 \pm 0.3$ & $34,569 \pm 5,364$ & $\mathrm{No} C t$ & 0 \\
\hline Leaf- 6 & $23 \pm 0.3$ & $171,461 \pm 9,524$ & N/A & N/A & No Ct & 0 \\
\hline Leaf-7 & $25 \pm 0.0$ & $36,568 \pm 951$ & N/A & N/A & $23.7 \pm 0.5$ & $118,160 \pm 9,177$ \\
\hline
\end{tabular}

${ }^{\mathrm{a} C o p i e s / \mu l \text {. }}$ 
Digital PCR Chip Loader and run on a ProFlex Base PCR System. Thermal cycling conditions consisted of an initial denaturation stage of $95^{\circ} \mathrm{C}$ for $10 \mathrm{~min}$, followed by 35 cycles of denaturation at $95^{\circ} \mathrm{C}$ for $30 \mathrm{~s}$, annealing at $60^{\circ} \mathrm{C}$ for $30 \mathrm{~s}$, and extension at $72^{\circ} \mathrm{C}$ for $30 \mathrm{~s}$, and a final extension of $5 \mathrm{~min}$ at $72^{\circ} \mathrm{C}$. End-point fluorescent data were collected on a QuantStudio 3D Digital PCR System and analyzed using the QuantStudio AnalysisSuite Cloud Software (https://www.thermofisher.com/us/en/home/life-science/pcr/digital-pcr/quantstudio-3ddigital-pcr-system/quantstudio-3d-software.html).

\section{Results}

Palm species and leaf tissue tested. Three palm species were identified at FLREC as exhibiting symptoms of LBD, which include $P$. roebelinii (three specimens), Sy. romanzoffiana (three specimens), and Sa. palmetto (three specimens) (Fig. 1) and test positive by qPCR (Table 1). For the Sy. romanzoffiana specimen, seven different samples were identified as suitable (Fig. 2) that will be referred to as Sro1 through Sro-7. The sample Sro-1 represents a fully desiccated leaf with a color that is natural to a healthy palm on senescing leaves (Fig. 2). The sample Sro-2 represents a desiccated leaf with the characteristic bronze color that is not observed in healthy palms (Fig. 2). The samples Sro-3 and Sro-4 represent leaves that are beginning to desiccate, while Sro-5 and Sro-6 are leaves without any observable symptoms (Fig. 2). The final sample, Sro-7, is taken from the spear

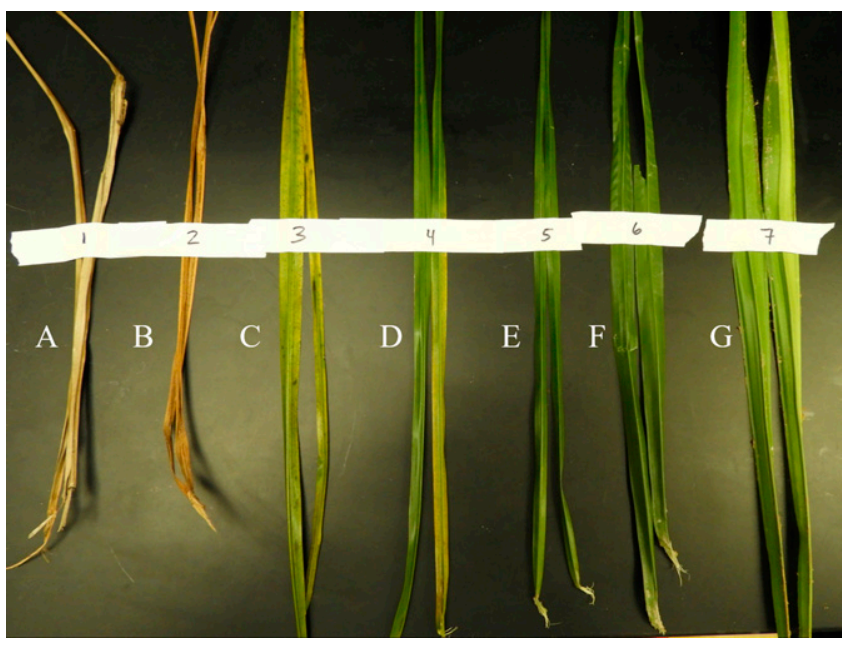

Fig. 2. Leaf tissue used for quantification of phytoplasma from infected Syagrus romanzoffiana: Sro-1 naturally senescing leaf (A), Sro-2 dead and bronze colored symptomatic leaf (B), Sro-3 dying leaf (C), Sro-4 dying leaf (D), Sro-5 asymptomatic leaf $(\mathbf{E})$, Sro-6 asymptomatic leaf $(\mathbf{F})$, and Sro-7 spear leaf $(\mathbf{G})$.

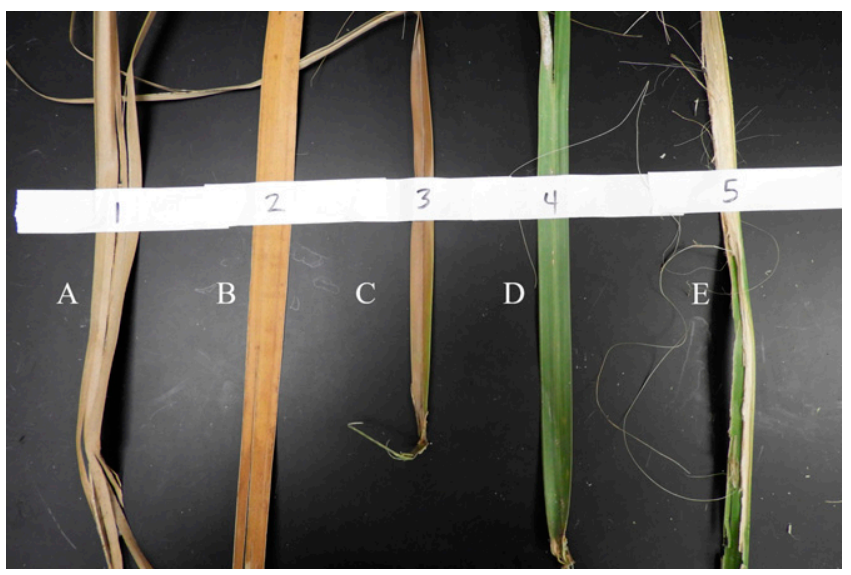

Fig. 3. Leaf tissue used for quantification of phytoplasma from infected Sabal palmetto: Spa-1 naturally senescing leaf (A), Spa-2 dead and bronze colored symptomatic leaf (B), Spa-3 dying leaf (C), Spa-4 asymptomatic leaf (D), Spa-5 spear leaf (E). leaf (Fig. 2), with no observable symptoms other than being bent over in the field. For the Sa. palmetto specimens, five different samples were taken (Fig. 3) that will be referred to as Spa-1 through Spa-5. The sample Spa-1 represents a fully desiccated leaf with a color that is natural to a healthy palm on senescing leaves (Fig. 3). The sample Spa-2 represents a desiccated leaf with the characteristic bronze color that is not observed in healthy palms (Fig. 3). The sample Spa-3 represents a partially desiccated leaf (Fig. 3), and Spa-4 represents a leaf without any observable symptoms (Fig. 3). The sample Spa-5 is the spear leaf with no observable symptoms (Fig. 3) other than being bent over in the field. For the $P$. roebelinii specimen, seven different leaf samples were taken (Fig. 4) and are labeled Pro-1 through Pro-7. The sample Pro-1 represents a fully desiccated leaf with a color that is natural to a healthy palm on senescing leaves (Fig. 2). The sample Pro-2 represents a desiccated leaf with the characteristic bronze color that is not observed in healthy palms (Fig. 2). The sample Pro-3 represents a leaf showing early signs of desiccation (Fig. 4), and on this specimen, all leaves had some degree of desiccation and not completely green leaves were observed. Samples Pro-4 through Pro-7 represent various spear leaves at various stages of development with Pro-7 being the newest and primary spear leaf (Fig. 4). While Pro-4 through Pro-6 are not true spear leaves, they are still developing and thus still directly connected to the meristem of the palm (Fig. 4). The terms secondary spear leaf, tertiary spear leaf, and quaternary spear leaf are designated for samples Pro-6, Pro-5, and Pro4 , respectively.

Subgroup classification of phytoplasma isolates. All isolates obtained in this study yielded a Tm product that was consistent with 16SrIV-D Tm products found by Bahder et al. (2017) and matched the 16SrIV-D controls used in this study (Table 2), confirming that the phytoplasma being analyzed in this study was subgroup D and not subgroup A. The variation observed among the isolates in this

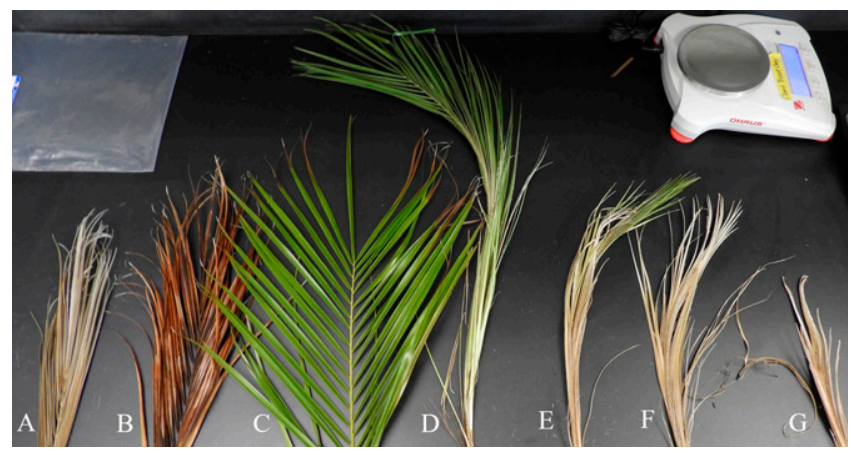

Fig. 4. Leaf tissue used for quantification of phytoplasma from infected Phoenix roebelinii; Pro-1 naturally senescing leaf (A), Pro-2 dead and bronze colored symptomatic leaf (B), Pro-3 dying leaf (C), Pro-4 quaternary spear leaf (D), Pro-5 tertiary spear leaf $(\mathbf{E})$, Pro-6 secondary spear leaf $(\mathbf{F})$, and Pro-7 primary spear leaf (G)

Table 2. qPCR and melt curve analysis of isolates examined in this study for verification of subgroup classification in the 16SrIV taxonomic group

\begin{tabular}{lcc}
\hline Sample & $\mathbf{C t}$ & Tm $\left({ }^{\circ} \mathbf{C}\right)$ \\
\hline Phoenix roebelinii-1 & 20.6 & 80.13 \\
Phoenix roebelinii-2 & 19.8 & 80.13 \\
Phoenix roebelinii-3 & 20.3 & 80.04 \\
Sabal palmetto-1 & 21.4 & 80.04 \\
Sabal palmetto-2 & 20.9 & 80.04 \\
Sabal palmetto-3 & 23.3 & 80.04 \\
Syagrus romanzoffiana-1 & 22.4 & 80.04 \\
Syagrus romanzoffiana-2 & 25.4 & 80.04 \\
Syagrus romanzoffiana-3 & 23.7 & 80.04 \\
16SrIV-A (+) control & 21.5 & 80.53 \\
16SrIV-D (+) control & 19.3 & 80.13 \\
Water (-) control & No Ct & 64.13 \\
\hline
\end{tabular}


study falls within observed variation of the Tm product observed for the 16SrIV-D phytoplasma by Bahder et al. (2017). In addition, the melt curve for each isolate was plotted against the 16SrIV-A and 16SrIV-D controls for the normalized and derivative reporter. The melt curve for isolates representing each species tested aligned with the melt curve for the 16SrIV-D control (Fig. 5).

Quantification of phytoplasma in leaf tissue by qPCR. For all species tested, phytoplasma was undetectable in fully desiccated leaves, both the naturally senesced leaves and bronze colored, symptomatic leaves (Table 1). Additionally, partially desiccated leaf tissue for all species tested negative for phytoplasma (Table 1). For both Sy. romanzoffiana and $S a$. palmetto, the leaf tissue that did not display any observable symptoms tested negative for phytoplasma (Table 1). For the Sy. romanzoffiana and Sa. palmetto specimens, the only leaf tissue that gave a positive reaction for the phytoplasma was the material obtained from the spear leaf (Table 1). For the $P$. roebelinii specimen, samples Pro-4, Pro-5, Pro-6, and Pro-7 all tested positive for the presence of phytoplasma (Table 1). The Sy. romanzoffiana specimens had the overall highest level of phytoplasma with an average of $118,160 \pm 9,177$ copies/ $\mu l$ in the primary spear leaf while $P$. roebelinii and $S a$. palmetto had an average of $36,568 \pm$ 951 and 34,569 $\pm 5,364$ copies/ $\mu 1$, respectively. The $P$. roebelinii specimens also had an increase in phytoplasma titer in the secondary (Pro-6) spear leaf $(171,461 \pm 9,524$ copies/ $\mu 1)$ with a continuation of this trend into the tertiary (Pro-5) spear leaf $(370,471 \pm 45,377$ copies/ $\mu l)$ and quaternary (Pro-4) spear leaf $(868,410 \pm 47,741$ copies/ $\mu 1)$. For $S y$. romanzoffiana, a higher amount of phytoplasma was detected in the spear lead than the trunk tissue (Table 1). In Sa. palmetto, however, a higher amount of phytoplasma was measured in the trunk than in the spear leaf (Table 1 ). In $P$. roebelinii, there was more phytoplasma present in the trunk than in the primary (Pro-7) spear leaf but less when compared with Pro-6, -5, and -4 (Table 1).

Quantification of phytoplasma in leaf tissue by dPCR. For $S a$. palmetto and Sy. romanzoffiana, phytoplasma was only detectable in the spear leaf tissue (Table 3). In P. roebelinii, phytoplasma was detected in the primary spear leaf (Pro-7) as well as samples Pro-6, Pro5, and Pro-4 (Table 4). The lowest level of phytoplasma was detected in Pro-7 and increased in Pro-6, Pro-5, and Pro-4 (Table 5).

\section{Discussion}

The detection and quantification of the 16SrIV-D phytoplasma in the spear leaf tissue and the apparent absence in other leaves is useful both from an epidemiological perspective as well as an applied perspective. To our knowledge, this is the first study to investigate the occurrence and distribution of the 16SrIV-D phytoplasma in palm leaf tissue. Previous studies have documented the 16SrIV-A phytoplasma in spear leaf tissue of Cocos nucifera (Harrison et al. 1994) and recently quantified the distribution of the $16 \mathrm{SrIV}-\mathrm{A}$ phytoplasma in different tissues of $C$. nucifera (Córdova et al. 2014). dPCR was selected to compliment qPCR data due to its higher level of sensitivity for detecting palm phytoplasmas over standard and nested PCR (Bahder et al. 2018b). Because of comparable levels of sensitivity in detection of palm phytoplasmas between qPCR and nested PCR (Bahder et al. 2018b), using this approach was not desired because we would expect identical results. Because dPCR is more sensitive, it would be assumed that it would detect phytoplasma in certain leaf tissue that was not detectable by qPCR if it was present at lower titers.

The consistency between the dPCR results and qPCR results showing the presence of the phytoplasma in the spear leaf is a strong indicator that newly emerged spear leaves are the likely site of acquisition by the insect vector. If the spear leaf is the only tissue where the 16SrIV-D phytoplasma is present or if it is the only location where it is present at a level that is conducive to acquisition by an insect vector, this will aid transmission studies focused on vector discovery and ecology. Instead of randomly collecting insects from infected palms or from habitat near infected palms, insects on the spear leaves can be

Table 3. Digital PCR results for leaf tissue in Phoenix roebelinii

\begin{tabular}{lcrrrr}
\hline Sample & $\begin{array}{c}\text { Total } \\
\text { wells }\end{array}$ & $\begin{array}{c}\text { Positive } \\
\text { wells }\end{array}$ & $\begin{array}{c}\text { Negative } \\
\text { wells }\end{array}$ & $\begin{array}{c}\text { Copies/ } \\
\boldsymbol{\mu l}\end{array}$ & Precision \\
\hline 1 & 17,244 & 0 & 17,244 & 0 & $45.677 \%$ \\
2 & 18,001 & 0 & 18,001 & 0 & $67.12 \%$ \\
3 & 18,056 & 0 & 18,056 & 0 & $45.333 \%$ \\
4 & 17,666 & 17,413 & 253 & $1,440,000$ & $2.995 \%$ \\
5 & 18,076 & 15,650 & 2,426 & 670,180 & $1.876 \%$ \\
6 & 18,020 & 11,078 & 6,942 & 634,000 & $1.96 \%$ \\
7 & 17,472 & 2,914 & 14,558 & 121,000 & $3.706 \%$ \\
$(+)$ control & 17,666 & 10,615 & 7,051 & 121,000 & $2.995 \%$ \\
$(-)$ control $^{\mathrm{a}}$ & 16,683 & 0 & 16,683 & 0 & $49.195 \%$ \\
$(-)$ control $^{\mathrm{b}}$ & 17,286 & 0 & 17,286 & 0 & $32.111 \%$ \\
\hline
\end{tabular}

a Healthy.

b Water.

Table 4. Digital PCR results for leaf tissue in Sabal palmetto

\begin{tabular}{|c|c|c|c|c|c|}
\hline Sample & $\begin{array}{l}\text { Total } \\
\text { wells }\end{array}$ & $\begin{array}{c}\text { Positive } \\
\text { wells }\end{array}$ & $\begin{array}{l}\text { Negative } \\
\text { wells }\end{array}$ & $\begin{array}{c}\text { Copies/ } \\
\boldsymbol{\mu l}\end{array}$ & Precision \\
\hline Spa-1 & 17,294 & 0 & 17,294 & 0 & $50.485 \%$ \\
\hline Spa-2 & 16,891 & 0 & 16,891 & 0 & $85.857 \%$ \\
\hline Spa-3 & 17,280 & 0 & 17,280 & 0 & $99.964 \%$ \\
\hline Spa-4 & 16,898 & 0 & 16,898 & 0 & $166.45 \%$ \\
\hline Spa-5 & 18,353 & 3,859 & 14,494 & 15,645 & $3.216 \%$ \\
\hline$(+)$ control & 17,666 & 10,615 & 7,051 & 144,000 & $2.995 \%$ \\
\hline (-) control $^{\mathrm{a}}$ & 16,683 & 0 & 16,683 & 0 & $49.195 \%$ \\
\hline (-) control $^{\mathrm{b}}$ & 17,286 & 0 & 17,286 & 0 & $32.111 \%$ \\
\hline
\end{tabular}

a Healthy.

b Water.
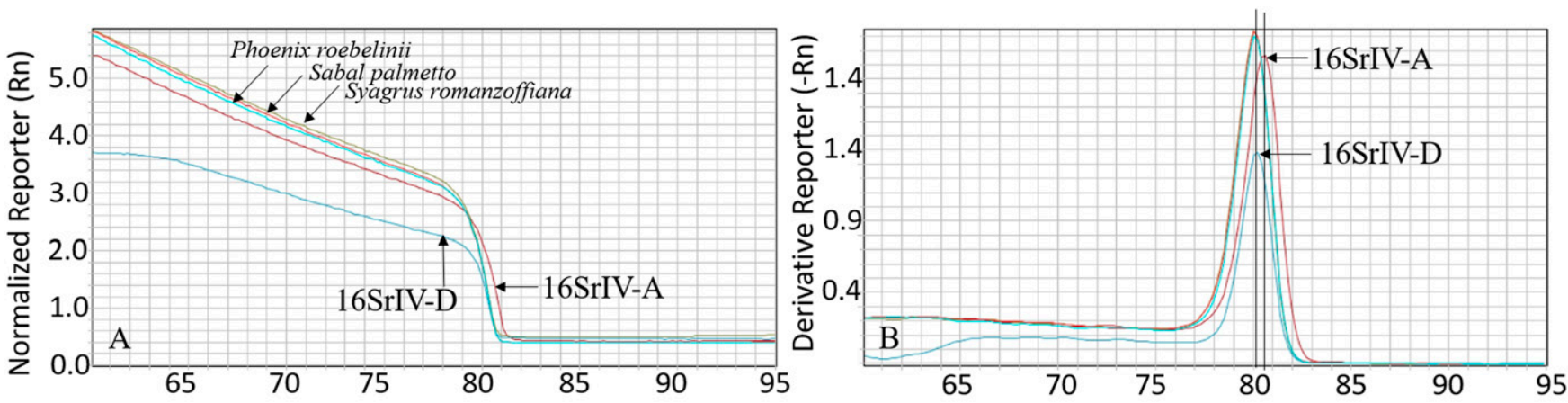

Temperature $\left(\mathrm{C}^{\circ}\right)$

Fig. 5. Melt curve plots for isolates of the 16SrIV-D phytoplasma obtained from the three palm species examined in this study for the normalized reporter (A) and derivative reporter (B). 
Table 5. Digital PCR results for leaf tissue in Syagrus romanzoffiana

\begin{tabular}{lcrrrr}
\hline Sample & $\begin{array}{c}\text { Total } \\
\text { wells }\end{array}$ & $\begin{array}{c}\text { Positive } \\
\text { wells }\end{array}$ & $\begin{array}{c}\text { Negative } \\
\text { wells }\end{array}$ & $\begin{array}{c}\text { Copies/ } \\
\boldsymbol{\mu l}\end{array}$ & \begin{tabular}{c} 
Precision \\
\hline 1
\end{tabular} \\
\hline 16,482 & 0 & 16,482 & 0 & $210.06 \%$ \\
2 & 16,766 & 0 & 16,766 & 0 & $42.195 \%$ \\
3 & 17,029 & 0 & 17,029 & 0 & $65.876 \%$ \\
4 & 17,303 & 0 & 17,303 & 0 & $140.26 \%$ \\
5 & 17,571 & 0 & 17,571 & 0 & $33.508 \%$ \\
6 & 17,584 & 0 & 17,584 & 0 & $53.374 \%$ \\
7 & 17,472 & 2,914 & 14,558 & 8,426 & $3.706 \%$ \\
$(+)$ control $^{a}$ & 17,666 & 10,615 & 7,051 & 144,000 & $2.995 \%$ \\
$(-)$ control $^{\mathrm{a}}$ & 16,683 & 0 & 16,683 & 0 & $49.195 \%$ \\
$(-)$ control $^{\mathrm{b}}$ & 17,286 & 0 & 17,286 & 0 & $32.111 \%$ \\
\hline
\end{tabular}

a Healthy.

b Water.

targeted to increase the likelihood of collecting individuals that have acquired the phytoplasma to use for transmission bioassays.

Additionally, these data can benefit nurseries and landscape companies with regard to sampling for diagnostic purposes. Historically, palm trunk tissue is recommended for sampling and testing due to the higher level of phytoplasma (Harrison and Elliott 2016; Harrison et al. 1992) relative to mature leaf tissue. However, in certain instances, using trunk tissue is not possible either due to the palm being younger and lacking a trunk or the customer not wanting a hole created in their palm. In these cases, using a section of the spear leaf would be a viable option for sampling and testing that would not put the palm at significant risk or reduce the aesthetic value of the palm.

The results found in this study contradict the findings by Córdova et al. (2014) where very low levels of the 16SrIV-A phytoplasma were found in the spear leaf and higher levels were found in the trunk. The exception to this was with Sa. palmetto, where more phytoplasma was detected in the trunk. However, substantial levels were also detected in the spear leaf. The fact that Córdova et al. (2014) used $C$. nucifera and 16SrIV-A could explain the difference in findings; however, the disease stage at which the samples were taken could also account for variation between these studies and potentially explain the difference between $\mathrm{Sa}$. palmetto and $\mathrm{Sy}$. romanzoffiana and $P$. roebelinii in this study. For other phytoplasma groups, leaf tissue has been shown to have the highest titers of phytoplasma as measured by qPCR (Christensen et al. 2004) but also high levels of variation among experimental units in terms of levels of phytoplasma detected.

These results provide valuable insights into the biology of the 16SrIV-D phytoplasma in susceptible palm hosts that will aid in improving the efficiency of vector studies but also benefit stakeholders by providing an additional sampling option. In addition, these results may contribute to management programs aimed at reduction of disease spread by either treating or covering spear leaf tissue during time periods of peak vector populations to reduce acquisition/inoculation likelihood. Future research efforts should attempt to determine if this trend is present in other species of susceptible palms.

\section{Literature Cited}

Bahder, B. W., and Helmick, E. E. 2018a. Lethal yellowing (LY) of palm. UF/ IFAS Extension document PP-222.

Bahder, B. W., and Helmick, E. E. 2018b. Sampling palms for lethal yellowing and Texas phoenix palm decline phytoplasmas. UF/IFAS Extension document ENY-990.

Bahder, B. W., Helmick, E. E., Chakrabati, S., Osorio, S., Soto, N., Chouvenc, T., and Harrison, N. A. 2018a. Disease progression of a lethal decline caused by the 16SrIV-D phytoplasma in Florida palms. Plant Pathol. 67:1821-1828.

Bahder, B. W., Helmick, E. E., and Harrison, N. A. 2017. Detecting and differentiating phytoplasmas belonging to subgroups $16 \mathrm{SrIV}-\mathrm{A}$ and $16 \mathrm{SrIV}-$ $\mathrm{D}$ associated with lethal declines of palms in Florida using qPCR and highresolution melt analysis (HRMA). Plant Dis. 101:1449-1454.

Bahder, B. W., Helmick, E. E., Mou, D., Harrison, N. A., and Davis, R. 2018b. Digital PCR technology for detection of palm-infecting phytoplasmas belonging to group 16SrIV that occur in Florida. Plant Dis. 102:1008-1014.

Christensen, N. M., Nicolaisen, M., Hansen, M., and Schulz, A. 2004. Distribution of phytoplasma in infected plants as revealed by real-time PCR and bioimaging. Mol. Plant-Microbe Interact. 17:1175-1184.

Córdova, I., Oropeza, C., Puch-Hau, C., Harrison, N., Collí-Rodríguez, A., Narvaez, M., Nic-Matos, G., Reyes, C., and Sáenz, L. 2014. A real-time PCR assay for detection of coconut lethal yellowing phytoplasmas of group 16SrIV subgroups A, D, and E found in the Americas. J. Plant Pathol. 96: 343-352.

Dey, K. K., Jeyaprakash, A., Hansen, J., Jones, D., Smith, T., Davison, D., Srivastava, P., Bahder, B., Li, C., and Sun, X. 2018. First report of the 16SrIV-D phytoplasma associated with decline of a Bismarck Palm (Bismarckia nobilis). Plant Health Prog. 19:128.

Harrison, N. A., Bourne, C. M., Cox, R. L., Tsai, J. H., and Richardson, P. A. 1992 DNA probes for detection of mycoplasmalike organisms associated with lethal yellowing disease of palms in Florida. Phytopathology 82:216-224.

Harrison, N.A. and Elliott, M.L. 2016. Texas Phoenix Palm Decline. UF/IFAS Extension document PP243.

Harrison, N. A., Helmick, E. E., and Elliott, M. L. 2008. Lethal yellowing-type diseases of palms associated with phytoplasma newly identified in Florida USA. Ann. Appl. Biol. 153:85-94.

Harrison, N. A., Helmick, E. E., and Elliott, M. L. 2009. First report of a phytoplasma-associated lethal decline of Sabal palmetto in Florida, USA. Plant Pathol. 58:792.

Harrison, N. A., Richardson, P. A., Jones, P., Tymon, A. M., Eden-Green, S. J., and Mpunami, A. A. 1994. Comparative investigation of MLOs associated with Caribbean and African coconut lethal decline diseases by DNA hybridization and PCR assays. Plant Dis. 78:507-511.

Harrison, N. A., Womack, M., and Carpio, M. L. 2002. Detection and characterization of a lethal Yellowing (16SrIV) group phytoplasma in Canary Island Date Palms affected by lethal decline in Texas. Plant Dis. 86:676-681.

Jeyaprakash, A., Sutton, B. D., Halbert, S. E., and Schubert, T. S. 2011. First report of a 16SrIV-D phytoplasma associated with Texas Phoenix Palm Decline on Pigmy Date Palm (Phoenix roebelinii) in Florida. Plant Dis. 95:1475. 